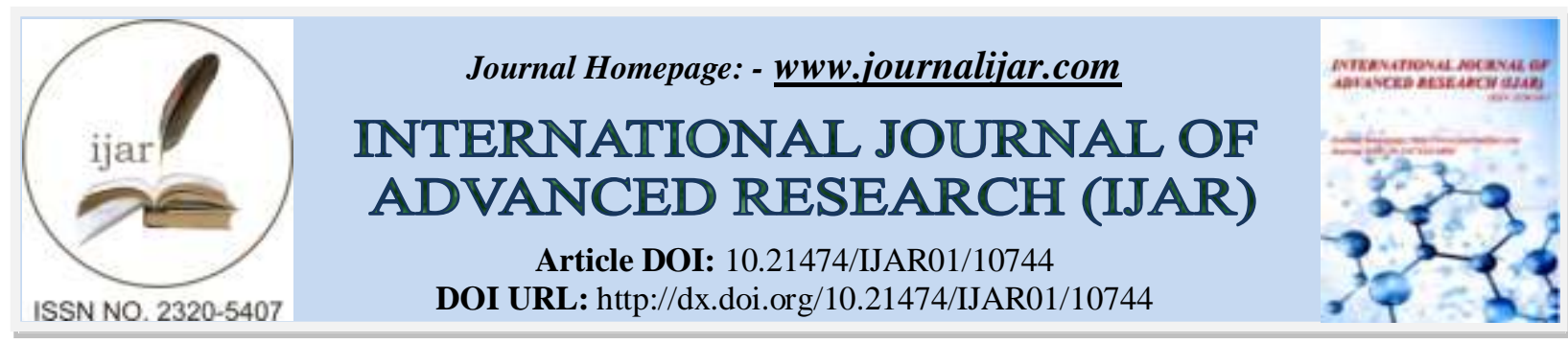

RESEARCH ARTICLE

\title{
EFFECTIVENESS OF RELAXATION THERAPY ON PSYCHOLOGICAL VARIABLES AMONG ELDERLY RESIDING IN HOMES FOR THE AGED
}

\author{
Alphonsa K.K ${ }^{1}$, Jijimole Mathew ${ }^{2}$, Jaleel Abdul $A^{3}$ and Vijayaraghavan $\mathbf{R}^{4}$ \\ 1. Vice Principal, St. John's College of Nursing, St. John's National Academy of Health Sciences, Bangalore, \\ Karnataka, India. \\ 2. Professor and HOD of OBG Department. Little Flower College of Nursing Angamaly. \\ 3. Department of Surgery, Karuna Medical College, Palakkad, Kerala, India, \\ 4. Department of Research, Saveetha University, Chennai, Tamil Nadu, India.
}

\section{Manuscript Info}

Manuscript History

Received: 05 February 2020

Final Accepted: 07 March 2020

Published: April 2020

\begin{abstract}
Background: Aging is an inevitable developmental phenomenon. As a person ages, possibility of problems multiply. Psychological wellbeing is the basic requisite for the healthy life of the elderly. Recent years have seen the prevalence of depression and dementia. The body's natural relaxation response is a powerful antidote to stress. Relaxation techniques such as deep breathing, visualization, progressive muscle relaxation, music, physical exercise, meditation and yoga can help to activate the relaxation response.

Objective: To assess the effect of relaxation therapy on psychological variables among elderly in selected homes for the aged.

Materials and Methods: True experimental pre-test, post-test design. 120 elderly clients from 12 old age homes were selected by stratified proportionate random sampling technique(Control:60; Experimental:60). Pre test was done with Demographic data sheet, Psychological problem assessment questionnaire (PPAQ), and DASS 21 for Control and Experimental group. Control group had their normal routines, whereas exp group had Jacobson's progressive muscle relaxation technique (JPMR), music, physical exercise and laughter therapy.Posttest was done on 30th day and 120th Data analysis and interpretation was done by descriptive and inferential statistics. Results: The study showed the effectiveness of relaxation therapy on psychological problems among elderly people in control and experimental groups at $<0.001$ respectively which was statistically significant. There was also effectiveness of relaxation therapy on depression, anxiety and stress at $<0.001$ respectively.
\end{abstract}

Copy Right, IJAR, 2020,. All rights reserved.

\section{Introduction:-}

Older people face special physical and mental challenges that need to be addressed on a war footing because of the fast-growing number of elderly in relation to the younger population. Most particularly, in developing countries, the multitude of issues concerning older people has become a major challenge for everyone. The major psychological factors related to old age are disrespect, death of dear ones, strained in-house relations, disappointment, mental 
tension, loneliness and lack of freedom. Senility, dementia, sexual problems and emotional disorders arise due to hormonal changes (Muttikkal et al, 2014).

Psychological changes in normal aging include loss of self- esteem, non-acceptance of physical changes, coping with personal loss, diminished processing of information and possible depression (Mathuranath, et al, 2010). Mental changes include gradual mental dysfunction, declining intellectual facility and memory and sensory changes all of which can result in inaccurate communication and disruption of sleep (Catherine et al, 2011).

An inexpensive way of dealing with such a widespread problem appears to be the introduction of relaxation therapy. Thus, the researcher undertook the task of assessing the effect of relaxation therapy on variables such as psychological problems, depression, anxiety and stress among elderly in old age homes. The ultimate aim is to promote relaxation therapy as an effective method of ameliorating the problem.

\section{Materials and Methods:-}

The research method used was a quantitative evaluative approach with true experimental pre-test, post-test and a control group design. Twelve homes for the aged in Ernakulam district, Kerala were selected. 120 elderly clients from 12 old age homes who fulfilled the inclusion and exclusion criteria (after screening) were selected by stratified proportionate random sampling technique(Control group:60 elderly; Experimental group:60 elderly). Pre test was done with Demographic data sheet, Psychological problem assessment questionnaire (PPAQ), and DASS 21 for Control and Experimental group. Control group had their routine activities of the home for the aged, whereas the experimental group: underwent 4 months relaxation therapy with Jacobson's progressive muscle relaxation technique (JPMR) with background music one hour in the morning, physical exercise and laughter therapy one hour in the evening. Posttest for both the groups was done on 30th day and 120th day (after 1 month and 4 months) with the same questionnaire. Data analysis and interpretation was done by descriptive and inferential statistics.

\section{Results:-}

Table - 1:- Description of elderly, according to their demographic characteristics.

\begin{tabular}{|c|c|c|c|c|c|c|}
\hline \multirow[t]{2}{*}{ S. No. } & \multirow[t]{2}{*}{ Categories } & \multicolumn{2}{|c|}{ Control group } & \multicolumn{2}{|c|}{$\begin{array}{l}\text { Experimental } \\
\text { Group }\end{array}$} & \multirow[t]{2}{*}{$x^{2,}$ Value, df, P- Value } \\
\hline & & n (60) & $\%$ & n (60) & $\%$ & \\
\hline \multirow[t]{3}{*}{1} & \multicolumn{5}{|l|}{ Age } & \multirow{3}{*}{$\begin{array}{l}0, \mathrm{df}=1 \\
\mathrm{P}=1.000\end{array}$} \\
\hline & $60-70$ & 30 & 50 & 30 & 50 & \\
\hline & $71-80$ & 30 & 50 & 30 & 50 & \\
\hline \multirow[t]{3}{*}{2} & \multicolumn{5}{|l|}{ Gender } & \multirow{3}{*}{$\begin{array}{l}0, \mathrm{df}=1 \\
\mathrm{P}=1.00\end{array}$} \\
\hline & Male & 30 & 50 & 30 & 50 & \\
\hline & Female & 30 & 50 & 30 & 50 & \\
\hline \multirow[t]{5}{*}{3} & \multicolumn{5}{|l|}{ Religion } & \multirow{5}{*}{$\begin{array}{l}3.41 \\
\mathrm{df}=2 \\
\mathrm{P}=0.182\end{array}$} \\
\hline & Hindu & 21 & 35 & 12 & 20 & \\
\hline & Christian & 38 & 63 & 47 & 78 & \\
\hline & Muslim & - & - & - & - & \\
\hline & Any other & 1 & 2 & 1 & 2 & \\
\hline \multirow[t]{6}{*}{4} & Education & & & & & \multirow{6}{*}{$\begin{array}{l}1.53 \\
d f=4 P=.821\end{array}$} \\
\hline & Illiterate & 9 & 15 & 8 & 13 & \\
\hline & Primary & 30 & 50 & 28 & 47 & \\
\hline & High School & 13 & 22 & 12 & 20 & \\
\hline & $\begin{array}{l}\text { Higher } \\
\text { Secondary }\end{array}$ & 6 & 10 & 7 & 12 & \\
\hline & Graduate & 2 & 3 & 5 & 8 & \\
\hline \multirow[t]{5}{*}{5} & Marital Statu & & & & & \multirow{5}{*}{$\begin{array}{l}32.6 \\
d f=3 \\
P=0.0001\end{array}$} \\
\hline & Single & 6 & 10 & 29 & 48 & \\
\hline & Married & 29 & 48 & 28 & 47 & \\
\hline & Divorced & 11 & 18 & 2 & 3 & \\
\hline & $\begin{array}{l}\text { Widow/ } \\
\text { widower }\end{array}$ & 14 & 24 & 1 & 2 & \\
\hline
\end{tabular}




\begin{tabular}{|c|c|c|c|c|c|c|}
\hline \multirow[t]{3}{*}{6} & \multicolumn{5}{|l|}{ Work status } & \multirow{3}{*}{$\begin{array}{l}0, d f=1 \\
P=1.000\end{array}$} \\
\hline & Employed & 3 & 5 & 3 & 5 & \\
\hline & unemployed & 57 & 95 & 57 & 95 & \\
\hline \multirow[t]{3}{*}{7} & \multicolumn{5}{|c|}{ Type of family } & \multirow{3}{*}{$\begin{array}{l}0.036 \\
\mathrm{df}=1 \\
\mathrm{P}=0.846\end{array}$} \\
\hline & Nuclear & 38 & 63 & 39 & 65 & \\
\hline & Joint & 22 & 37 & 21 & 35 & \\
\hline \multirow[t]{3}{*}{8} & \multicolumn{5}{|c|}{ Medical Problems } & \multirow{5}{*}{$\begin{array}{l}0.635 \\
\mathrm{df}=1 \\
\mathrm{P}=0.426 \\
\mathbf{x}^{\mathbf{2}, \text { Value, }} \mathbf{d f}, \mathbf{P} \text { - Value }\end{array}$} \\
\hline & Yes & 40 & 67 & 44 & 73 & \\
\hline & No & 20 & 33 & 16 & 27 & \\
\hline \multirow[t]{2}{*}{ S. No } & \multirow[t]{2}{*}{ Categories } & \multicolumn{2}{|c|}{ Control group } & \multicolumn{2}{|c|}{$\begin{array}{l}\text { Experimental } \\
\text { Group }\end{array}$} & \\
\hline & & n (60) & $\%$ & $\mathrm{n}(60)$ & $\%$ & \\
\hline \multirow[t]{7}{*}{9} & \multicolumn{5}{|l|}{ Length of stay } & \multirow{7}{*}{$\begin{array}{l}6.65 \\
d f=4 \\
P=0.156\end{array}$} \\
\hline & $\begin{array}{l}\text { Less than } \\
\text { one year }\end{array}$ & 5 & 8 & 10 & 17 & \\
\hline & $2-5$ years & 36 & 60 & 36 & 60 & \\
\hline & 6-10 years & 15 & 25 & 6 & 10 & \\
\hline & $11-15$ years & 3 & 5 & 2 & 3 & \\
\hline & $16-20$ years & 1 & 2 & 3 & 5 & \\
\hline & $\begin{array}{l}\text { More than } 20 \\
\text { years }\end{array}$ & - & - & - & - & \\
\hline \multirow[t]{3}{*}{10} & \multicolumn{5}{|l|}{ History of DM } & \multirow{3}{*}{$\begin{array}{l}0.15 \\
\mathrm{df}=1 \\
\mathrm{P}=0.699\end{array}$} \\
\hline & Yes & 39 & 65 & 41 & 68 & \\
\hline & No & 21 & 35 & 19 & 32 & \\
\hline \multirow[t]{3}{*}{11} & \multicolumn{5}{|c|}{ History of HTN } & \multirow{3}{*}{$\begin{array}{l}0.833 \\
\mathrm{df}=1 \\
\mathrm{P}=0.361\end{array}$} \\
\hline & Yes & 50 & 83 & 46 & 77 & \\
\hline & No & 10 & 17 & 14 & 23 & \\
\hline \multirow[t]{5}{*}{12} & \multicolumn{5}{|c|}{ Duration of Medication } & \multirow{5}{*}{$\begin{array}{l}0.288 \\
\mathrm{df}=3 \\
\mathrm{P}=0.962\end{array}$} \\
\hline & $\begin{array}{l}\text { Below one } \\
\text { year }\end{array}$ & 32 & 53 & 33 & 55 & \\
\hline & $2-5$ years & 12 & 20 & 10 & 17 & \\
\hline & 5-10 years & 11 & 18 & 11 & 18 & \\
\hline & $\begin{array}{l}11 \text { and } \\
\text { above }\end{array}$ & 5 & 9 & 6 & 10 & \\
\hline \multirow[t]{3}{*}{13} & \multicolumn{5}{|c|}{ Psychiatric illness } & \multirow{3}{*}{$\begin{array}{l}0.484 \\
\mathrm{df}=1 \\
\mathrm{P}=0.487\end{array}$} \\
\hline & Yes & 10 & 17 & 13 & 22 & \\
\hline & No & 50 & 83 & 47 & 78 & \\
\hline 14 & History of Pra & 1 any rel & on 7 & & & 2 \\
\hline & Yes & 14 & 23 & 8 & 13 & $\mathrm{df}=1$ \\
\hline & No & 46 & 77 & 52 & 87 & $P=0.157$ \\
\hline
\end{tabular}


Table 2:-Psychological variables of elderly people with relaxation therapy in control and experimental group in pre test and post test.

\begin{tabular}{|c|c|c|c|c|c|c|c|}
\hline S No & Parameters & Group & $\begin{array}{l}\text { Mean } \pm S \\
\mathrm{E}\end{array}$ & $\begin{array}{l}\text { Median } \\
\left(25^{\text {th}}-75^{\text {th }}\right. \\
\text { percentile })\end{array}$ & $\begin{array}{l}\text { Con - pre } \\
\text { Exp- pre }\end{array}$ & $\begin{array}{l}\text { Con - P o1 } \\
\text { Exp - Po1 }\end{array}$ & $\begin{array}{l}\text { Con - Po2 } \\
\text { Exp - } \\
\text { Po2 }\end{array}$ \\
\hline \multirow[t]{6}{*}{1} & \multirow{6}{*}{$\begin{array}{l}\text { Psychological } \\
\text { problems }\end{array}$} & Con- pre & $72.7 \pm .10$ & $74(67-79)$ & \multirow{6}{*}{$\begin{array}{l}\mathrm{t}=3384 \\
\mathrm{p}=0.196\end{array}$} & \multirow{6}{*}{$\begin{array}{l}\mathrm{t}=5272 \\
\mathrm{p}=<0.001\end{array}$} & \multirow{6}{*}{$\begin{array}{l}\mathrm{t}=5414 \\
\mathrm{p}=<0.001\end{array}$} \\
\hline & & Con- po 1 & $72.8 \pm .90$ & $74.5(66-80)$ & & & \\
\hline & & Con- po 2 & $72.5 \pm .91$ & $74(67-79)$ & & & \\
\hline & & Exp-pre & $75.0 \pm .83$ & $77(69-82)$ & & & \\
\hline & & Exp- po 1 & $50.2 \pm .88$ & $50(43-54)$ & & & \\
\hline & & Exp- po 2 & $39.2 \pm .61$ & $40(35-42)$ & & & \\
\hline \multirow[t]{6}{*}{2} & \multirow[t]{6}{*}{ Depression } & Con- pre & $13.3 \pm 2.1$ & $14(12-15)$ & \multirow{6}{*}{$\begin{array}{l}\mathrm{t}=3197 \\
\mathrm{p}=0.022\end{array}$} & \multirow{6}{*}{$\begin{array}{l}\mathrm{t}=4760 \\
\mathrm{p}=<0.001\end{array}$} & \multirow{6}{*}{$\begin{array}{l}\mathrm{t}=5288 \\
\mathrm{p}=<0.001\end{array}$} \\
\hline & & Con- po 1 & $13.3 \pm 2.0$ & $13.5(12-14)$ & & & \\
\hline & & Con- po 2 & $13.4 \pm 1.8$ & $13.5(12-14)$ & & & \\
\hline & & Exp-pre & $14.3 \pm 2.1$ & $14(13-16)$ & & & \\
\hline & & Exp- po 1 & $10.9 \pm 1.5$ & $11(10-12)$ & & & \\
\hline & & Exp- po 2 & $9.1 \pm 1.5$ & $9(8-10)$ & & & \\
\hline \multirow[t]{6}{*}{3} & \multirow[t]{6}{*}{ Anxiety } & Con- pre & $13.9 \pm 2.1$ & $14(12-15)$ & \multirow{6}{*}{$\begin{array}{l}\mathrm{t}=4085 \\
\mathrm{p}=0.016\end{array}$} & \multirow{6}{*}{$\begin{array}{l}\mathrm{t}=5309 \\
\mathrm{p}=<0.001\end{array}$} & \multirow{6}{*}{$\begin{array}{l}\mathrm{t}=5409 \\
\mathrm{p}=<0.001\end{array}$} \\
\hline & & Con- po 1 & $13.9 \pm 2.0$ & $14(12-15)$ & & & \\
\hline & & Con- po 2 & $13.8 \pm 2.0$ & $14(12-15)$ & & & \\
\hline & & Exp- pre & $13.0 \pm 1.6$ & $13(12-14)$ & & & \\
\hline & & Exp- po 1 & $9.4 \pm 1.3$ & $9(8-10)$ & & & \\
\hline & & Exp- po 2 & $7.9 \pm 1.4$ & $8(7-9)$ & & & \\
\hline \multirow[t]{6}{*}{4} & \multirow[t]{6}{*}{ Stress } & Con-pre & $13.4 \pm 2.5$ & $14(12-15)$ & \multirow{6}{*}{$\begin{array}{l}\mathrm{t}=3307 \\
\mathrm{p}=0.087\end{array}$} & \multirow{6}{*}{$\begin{array}{l}\mathrm{t}=4462 \\
\mathrm{p}=<0.001\end{array}$} & \multirow{6}{*}{$\begin{array}{l}\mathrm{t}=5040 \\
\mathrm{p}=<0.001\end{array}$} \\
\hline & & Con- po 1 & $13.7 \pm 2.4$ & $14(12-15)$ & & & \\
\hline & & Con- po 2 & $13.6 \pm 2.4$ & $14(12-15)$ & & & \\
\hline & & Exp- pre & $14.2 \pm 2.0$ & $14(13-16)$ & & & \\
\hline & & Exp- po 1 & $12.0 \pm 1.8$ & $12(11-13)$ & & & \\
\hline & & Exp- po 2 & $10.1 \pm 1.4$ & $10(9-12)$ & & & \\
\hline \multicolumn{6}{|c|}{$\begin{array}{l}\mathrm{N}=60 \text { each } \\
\mathrm{Con}=\text { control group Exp=Experimental Group } \\
\text { Pre= Pre-test; po1= post-test } 1=1 \text { month } \\
\text { Po2= post-test } 2=4 \text { month }\end{array}$} & & \\
\hline
\end{tabular}

\section{Discussion:-}

Impaired memory, rigid thinking and fear of change are age-related manifestations. As stated before in this dissertation, reduction of income leads to a lower living standard, which aggravates a diminishing sense of wellbeing. Sexual changes also occur between the ages of 40 and 50 and later years. By virtue of nature, reproduction rates decrease among women and some diminution of sexual activity occurs in men. During this phase, physical and emotional disturbances may occur such as irritability, jealousy and despondency and other emotional disorders. The degree of adaptation to ageing is crucial to man's happiness in this phase of life. Failure to adapt can result in bitterness, inner withdrawal, depression, weariness of living and even suicide (Matteo et al, 2007). Psychological wellbeing is the basic requisite for the healthy life of the elderly. They should be in a sound status both physically and mentally. However, the actual state is different and more importantly worsened in the case of older people (Jessie et al, 2013).

A study done to assess the nature of stressors experienced by the age group between 60 and 80 years found that medical stressors were the most common cause of stressors. A survey done to assess the stress and coping strategies and quality of life between the institutionalized and non-institutionalized elderly involving 150 participants reported that there is more stress and less quality of life among the institutionalized compared to the non-institutionalized (Hae-Sook and Ruth, 2009).

An experimental study conducted on 30 subjects in homes for the aged between 60 and 85 years old demonstrated statistically significant difference between pre- and post-geriatric depression scale scores $(\mathrm{P}=0.005, \mathrm{t}=2.9709$, 
df = 29), which indicates that there is a reduction of depressive symptoms in older adults. There is a statistically significant difference in pre-and post-quality of life enjoyment and satisfaction questionnaire scores $(\mathrm{P}=$ $0.01, \mathrm{t}=2.5292, \mathrm{df}=29$ ), which indicates quality of life improvements among older adults and increase in the levels of enjoyment and satisfaction. In this study, the result showed that there was a reduction of depression from severe to mild ( $\mathrm{p}<0.001)$ among those studied (Nalin, Karen et al, 1997). A study for stress management and lifestyle change intervention for women 60 years and older using training in progressive muscle relaxation and guided imagery, abdominal breathing training using biofeedback, physical activity, and nutrition counseling, and cognitive restructuring training revealed that the intervention group experienced significantly greater reduction in perceived stress and physical and psychological stress symptoms compared to the control group. The intervention also significantly reduced depressive symptoms and improved quality of life for both variables) (Prakash et al, 2018).

\section{Conclusion:-}

With supportive evidence from the above-cited studies and the results obtained from the present study, the researcher concludes that a positive effect can be produced by relaxation therapy interventions on variables including psychological problems, depression, anxiety, and stress among the elderly.

\section{References:-}

1. Catherine Woodyard (2011). Exploring the therapeutic effects of yoga and its ability to increase quality of life, International Journal of Yoga, 4(2):49- 54.

2. Hae-Sook Jeon and Ruth E. Dunkle (2009). Stress and Depression among the Oldest-Old: A Longitudinal Analysis. Res Aging, 31(6):661-687

3. Jessie Dezutter, Sara Casalin, Amy Wachholtz, Koen Luyckx, Jessica Hekking, and Wim Vandewiele (2013). Meaning in Life: An Important Factor for the Psychological Wellbeing of Chronically Ill Patients? Rehabil Psychol. 58(4):334-341.

4. Mathuranath P. S., P. Joseph Cherian, Robert Mathew, Suresh Kumar, etal. (2010). Dementia in Kerala, South India: prevalence and influence of age, education and gender. Int JGeriatr Psychiatry, 25(3):290-297.

5. Nalin A. Singh, Karen M. Clements, and Maria A. Fiatarone (1997). A Randomized Controlled Trial of Progressive Resistance Training in Depressed Elders. Journal of Gerontology: Medical Sciences,52A(i):M27M35.

6. Prakash P., Nappinai Seran, Navaneetha, Malarvizhi, and Pradeep Thilakan (2018). Effectiveness of TIPER (Tailor Made Interventional Package to Enhance Relaxation) on Stress, Depression and Anxiety among Elders: A Pilot Study, International Journal of Health Sciences and Research, 8(30:186-192. 